\title{
Ultrasound-accelerated arylthiomethylation of indole via multicomponent reaction in water catalyzed by acetic acid
}

- Luu Thi Xuan Thi

University of Science, VNU-HCM

- Pham Quang Vinh

Le Hong Phong upper secondary school-Dong Nai

(Received on June $5^{\text {th }} 2016$, accepted on April $10^{\text {th }} 2017$ )

\begin{abstract}
Multicomponent reactions (MCRs) play an important role to create the molecular complexity in a one-step process. Based on the mechanism and process of Mannich-type reactions in the synthesis of Grammin, arylthiomethylation reactions of indole were performed by using three components: indole,
\end{abstract}

p-thiocresol and a solution of formaldehyde (36\%) under two activation conditions, e.g. magnetic stirring and ultrasonic irradiation. The main product, 3-(p-tolylthiomethyl)-1H-indole, was obtained in a moderate yield (54\%) under short irradiation (40 minutes) by probe sonicator.

Keywords: arylthiomethylation, ultrasound irradiation, acetic acid, and indole

\section{INTRODUCTION}

Mannich reaction classified into multicomponent reactions (MCRs), has been fairly extensively investigated, while there are few studies using thiols in place of amines for Mannich-type reaction, namely alkylthiomethylation and arylthiomethylation. The latter has been used widely in organic chemistry, especially in total synthesis of natural products, e.g. sesquiterpenes and antibiotics [1-5].

Formaldehyde is a very active substrate frequently used in three-component reactions in order to generate active methylene transition compounds (or methides) via the methylenation of electron-rich carbons with formaldehyde. Subsequently, these active methylene intermediates were trapped by $\alpha, \beta$ unsaturated ketones [1], $\alpha, \beta$-unsaturated esters [2], lactams $[3,4,6]$, thiols $[5,7]$, indole $[7,8]$, and polyarenes [9].

In pursuit of our work on the analogue of the Mannich reaction, we report the arylthiomethylation involving indole, $p$-thiocresol and the solution of formaldehyde $(36 \%)$ to produce 3-(ptolylthiomethyl)- $1 H$-indole under the assistance of ultrasound irradiation in comparison with the on under magnetic stirring (Fig. 1). According to our literature review on the three-component reaction of indole, alkanethiol/arenethiol and formaldehyde, it was found that only one article described the yield around $25 \%$ of desired products obtained for six-day magnetic stirring [8].

\section{Trang 80}




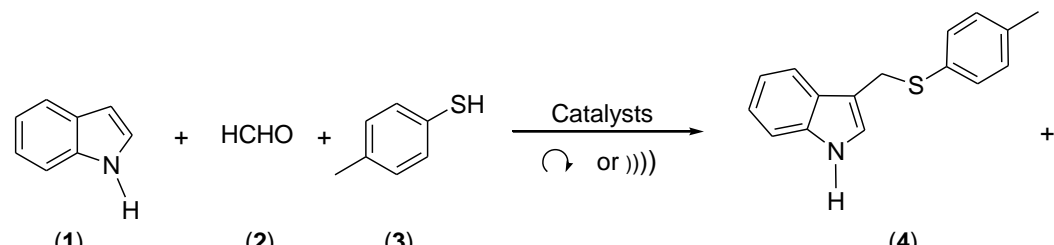

(1)

(2)

(3)

(4)

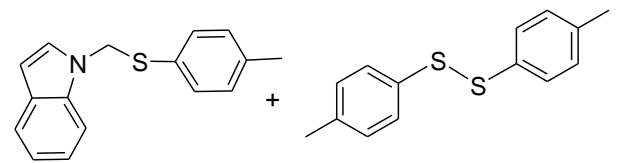

(5)

(6)

Fig. 1. Phenylthiomethylation involving indole, (1) $p$-thiocresol (3) and the solution of formaldehyde (2) to afford 3-(ptolylthiomethyl)- $1 H$-indole

\section{MATERIALS AND METHODS}

\section{Instrumentation}

Ultrasonic irradiation was performed by means of a probe sonicator GE130-41505L with 1/8" (3 mm) stepped microtip, operating at frequency $20 \mathrm{kHz}$. GC/MS analyses were performed on Agilent 7890A apparatus equipped with HP 5MS capillary column (30 $\mathrm{m} \times 250 \mu \mathrm{m} \times 0.25 \mu \mathrm{m})$ and 5973C VL MSD with Triple-Axis Detector, detector and injector temperature at $250{ }^{\circ} \mathrm{C}$, gas carrier (Helium) at 11.104 $\mathrm{mL} / \mathrm{min}$ (total flow), and oven temperature programme as follows: started at initial temperature is $50^{\circ} \mathrm{C}$ (maintained $2 \mathrm{~min}$ ), increased $10^{\circ} \mathrm{C} / \mathrm{min}$ up to $300^{\circ} \mathrm{C}$ (maintained $4 \mathrm{~min}$ ). GC analyses were performed on Agilent $6890 \mathrm{~N}$ apparatus equipped with capillary column $(30 \mathrm{~m} \times 320 \mu \mathrm{m} \times 0.25 \mu \mathrm{m})$, detector and injector temperature at $250{ }^{\circ} \mathrm{C}$, gas carrier (Nitrogen) at $1.0 \mathrm{~mL} / \mathrm{min}$ (total flow), and oven temperature programme as follows: started at initial temperature is $80^{\circ} \mathrm{C}$ (maintained $1 \mathrm{~min}$ ), increased 25 ${ }^{\circ} \mathrm{C} / \mathrm{min}$ up to $230{ }^{\circ} \mathrm{C}$ (maintained $1 \mathrm{~min}$ ) and continued increasing up to $300{ }^{\circ} \mathrm{C}$ (maintained 2 min). NMR spectra were recorded on Bruker 500 NMR spectrometer at $500 \mathrm{MHz}\left({ }^{1} \mathrm{H}\right)$ and $125 \mathrm{MHz}$ $\left({ }^{13} \mathrm{C}\right)$.

\section{Chemicals}

All commercially available chemicals used were purchased from Aldrich and analyzed for authenticity and purity by GC/MS prior to use.

General procedure of arylthiomethylation of indole with $p$-thiocresol and the solution of formaldehyde $(36 \%)$ into 3 -( $p$-tolylthiomethyl)- $1 H$ indole under ultrasound irradiation

$p$-Thiocresol (0.248 g, $2.0 \mathrm{mmol})$ was added into the $25 \mathrm{~mL}$ two-neck pear flask containing $6 \mathrm{~mL}$ of water, then glacial acetic acid $(0.180 \mathrm{~g}, 3 \mathrm{mmol})$, the formaldehyde ( $2.0 \mathrm{mmol}, 36 \%$ aq.) and the indole $(0.351 \mathrm{~g}, 3.0 \mathrm{mmol})$ were added successively. The flask was equipped with the ultrasound probe and irradiated at a suitable amplitude for a specific period of time. Subsequently, $7 \mathrm{~mL}$ of water was added and the $\mathrm{pH}$ was adjusted to $\mathrm{pH} 11-13$ by $20 \% \mathrm{NaOH}$ solution. The reaction mixture was extracted with dichloromethane ( 4 x $15 \mathrm{~mL})$. The combined extracts were washed with water until $\mathrm{pH} 8$, and then dried (anhydrous $\mathrm{Na}_{2} \mathrm{SO}_{4}$ ). After removal of the solvent by rotatory evaporation, the crude product was analysed by GC or GC/MS. The product was isolated by flash column chromatography (4-7 g silica gel, Davisil, grade 710, 4-20 $\mathrm{m}, 60 \mathrm{~A}, 99 \%$ ) using as eluent a mixture of hexane and ethyl acetate $(9: 1 \mathrm{v} / \mathrm{v})$. 


\section{Spectroscopic data}

The identity and purity of products reported were ensured by GC/MS and NMR spectroscopy as descriptions below:

3-( $p$-Tolylthiomethyl)- $1 H$-indole (4), $\mathrm{C}_{16} \mathrm{H}_{15} \mathrm{NS}(\mathrm{M}=253)$, white solid, mp 145-146 ${ }^{\circ} \mathrm{C}$. ${ }^{1} \mathrm{H}$ NMR (500 $\left.\mathrm{MHz} \mathrm{CDCl}_{3}\right) \delta_{\mathrm{H}}=7.53(\mathrm{~d}, J=8.0 \mathrm{~Hz}, 1 \mathrm{H}), 7.26(\mathrm{~d}, J=7.0 \mathrm{~Hz}, 1 \mathrm{H}), 7.19(\mathrm{t}, J=7.0 \mathrm{~Hz}, 1 \mathrm{H}), 7.09(\mathrm{~d}, J=8.0$ $\mathrm{Hz}, 1 \mathrm{H}), 7.07(\mathrm{~d}, J=8.0 \mathrm{~Hz}, 2 \mathrm{H}), 6.90(\mathrm{~d}, J=8.0 \mathrm{~Hz}, 2 \mathrm{H}), 6.54(\mathrm{~s}, 1 \mathrm{H}), 5.31(\mathrm{~s}, 2 \mathrm{H}), 2.27(\mathrm{~s}, 3 \mathrm{H}) .{ }^{13} \mathrm{C} \mathrm{NMR}$ $\left(125 \mathrm{MHz} \mathrm{CDCl}_{3}\right): \delta_{\mathrm{C}}=138.6,136.3,134.3$ (2C), 130.1, 129.9 (2C), 129.0, 126.0, 121.9, 119.6, 119.5, 115.4, 110.1, 29.9, 21.3. MS (EI, $70 \mathrm{eV}): m / z=253[\mathrm{M}]^{+}, 162,130,118,103,91,77$.

$N$-(p-Tolylthiomethyl)indole (5), $\mathrm{C}_{16} \mathrm{H}_{15} \mathrm{NS}(\mathrm{M}=253)$, white solid, mp $130-132{ }^{\circ} \mathrm{C} .{ }^{1} \mathrm{H} \mathrm{NMR}(500 \mathrm{MHz}$, $\left.\mathrm{CDCl}_{3}\right) \delta_{\mathrm{H}}=7.60(\mathrm{~d}, J=8.0 \mathrm{~Hz}, 1 \mathrm{H}), 7.29(\mathrm{dd}, J=8.0 \mathrm{~Hz}, J=0.5 \mathrm{~Hz}, 1 \mathrm{H}), 7.18(\mathrm{td}, J=8.0 \mathrm{~Hz}, J=1 \mathrm{~Hz}, 1 \mathrm{H})$, $7.10-7.13(\mathrm{~m}, 3 \mathrm{H}), 7.03(\mathrm{~d}, J=8.0 \mathrm{~Hz}, 2 \mathrm{H}), 6.81(\mathrm{~d}, J=3 \mathrm{~Hz}, 1 \mathrm{H}), 6.40(\mathrm{dd}, J=3.0 \mathrm{~Hz}, J=0.5 \mathrm{~Hz}, 1 \mathrm{H}), 5.39(\mathrm{~s}$, 2H) $2.31(\mathrm{~s}, 3 \mathrm{H}) .{ }^{13} \mathrm{C}$ NMR $\left(125 \mathrm{MHz}, \mathrm{CDCl}_{3}\right): \delta_{\mathrm{C}}=139.1,134.6(2 \mathrm{C}), 130.3(2 \mathrm{C}), 130.2,130.1,129.6,128.2$, 122.2, 121.4, 120.4, 110.4, 102.7, 53.0, 21.5. MS (EI, $70 \mathrm{eV}): \mathrm{m} / \mathrm{z}=253[\mathrm{M}]^{+}, 162,130,118,103,91,77$.

\section{RESULTS AND DISCUSSION}

At the beginning of this work, the reactions of indole, $p$-thiocresol and the solution of formaldehyde without using catalyst were performed under magnetic stirring for $2.5 \mathrm{~h}$. The results showed that the three-component reactions in the absence of the catalyst did not take place. This led us to test several catalysts such as $\mathrm{CH}_{3} \mathrm{COOH}, \mathrm{NiCl}_{2} \cdot 6 \mathrm{H}_{2} \mathrm{O}, \mathrm{Mg}-\mathrm{Al}$ Hydrotalcite, and $\mathrm{KF} / \mathrm{Al}_{2} \mathrm{O}_{3}$ (wt. $40 \%$ ) for this arylthiomethylation. Consequently, it was noticeable that acetic acid played a crucial role in our multicomponent reaction (Table 1).

Table 1. Effect of the catalyst nature on the arylthiomethylation of indole with $p$-thiocresol and the solution of formaldehyde $\mathrm{a}^{\mathrm{a}}$

\begin{tabular}{|c|c|c|c|c|c|c|c|}
\hline \multirow[t]{2}{*}{ Entry } & \multirow[t]{2}{*}{ Catalyst (mmol) } & \multicolumn{5}{|c|}{$\mathrm{GC}(\%)$} & \multirow[t]{2}{*}{ Yield $^{\mathrm{b}}(\%)$} \\
\hline & & 1 & 3 & 4 & 5 & 6 & \\
\hline 1 & None & 50.87 & 42.79 & 1.21 & 0 & 0 & 1 \\
\hline 2 & $\mathrm{CH}_{3} \mathrm{COOH}$ & 0 & 17.76 & 48.77 & 0 & 33.47 & 47 \\
\hline 3 & $\mathrm{NiCl}_{2} \cdot 6 \mathrm{H}_{2} \mathrm{O}$ & 85.63 & 2.41 & 2.20 & 0 & 1.92 & 2 \\
\hline 4 & Mg-Al Hydrotalcite & 4.49 & 91.39 & 0.95 & 1.25 & 1.92 & 0.6 \\
\hline 5 & $\mathrm{KF} / \mathrm{Al}_{2} \mathrm{O}_{3}$ wt. $40 \%$ & 4.08 & 62.87 & 4.18 & 5.61 & 5.64 & 4 \\
\hline \multicolumn{8}{|c|}{$\begin{array}{l}\text { a The reactions of } p \text {-thiocresol }(2.0 \mathrm{mmol}) \text { and indole }(2.0 \mathrm{mmol}) \text { with the solution of formaldehyde } 36 \%(2.0 \mathrm{mmol}) \\
\text { in the presence of catalyst }(3.0 \mathrm{mmol}) \text { were performed under magnetic stirring at room temperature for } 2.5 \mathrm{~h} \text {. } \\
\text { b Yields were calculated based on GC-FID analysis. }\end{array}$} \\
\hline
\end{tabular}

\section{Trang 82}

A series of experiments with different molar ratios between $p$-thiocresol and acetic acid, as well as $p$-thiocresol and indole, was carried out to improve the reaction yield (Entries 1-5, Table 2). The optimum yield was observed when $3.0 \mathrm{mmol}$ of acetic acid was utilized as catalyst; whereas the excessive amount of this acidic catalyst led to a remarkable reduction of product yield owing to the deactivation of indole ring from the protonation of nitrogen atom under acidic media. 
Table 2. Influence of reaction conditions on the yield of 3-(p-tolylthiomethyl)- $1 H$-indole ${ }^{\mathrm{a}}$

\begin{tabular}{|c|c|c|c|c|}
\hline Entry & Indole (mmol) & $\mathrm{CH}_{3} \mathrm{COOH}(\mathrm{mmol})$ & Time (h) & Yield $^{\mathrm{b}}(\%)$ \\
\hline 1 & 2.0 & 1.5 & 2.5 & 29 \\
\hline 2 & 2.0 & 3.0 & 2.5 & 43 \\
\hline 3 & 2.0 & 4.5 & 2.5 & 37 \\
\hline 4 & 3.0 & 3.0 & 2.5 & 51 \\
\hline 5 & 4.0 & 3.0 & 2.5 & 47 \\
\hline 6 & 3.0 & 3.0 & 1.5 & 10 \\
\hline 7 & 3.0 & 3.0 & 3.5 & 53 \\
\hline 8 & 3.0 & 3.0 & 24 & 45 \\
\hline $9^{c}$ & 3.0 & 3.0 & $30 \mathrm{~min}$ & 16 \\
\hline $10^{\mathrm{c}}$ & 3.0 & 3.0 & $40 \mathrm{~min}$ & 54 \\
\hline $11^{\mathrm{c}}$ & 3.0 & 3.0 & $50 \mathrm{~min}$ & 41 \\
\hline $12^{c}$ & 3.0 & 3.0 & $60 \mathrm{~min}$ & 36 \\
\hline \multicolumn{5}{|c|}{$\begin{array}{l}{ }^{\mathrm{a}} \text { The reactions with a fixed amount of formaldehyde }(2.0 \mathrm{mmol}) \text { and } p \text {-thiocresol } \\
(2.0 \mathrm{mmol}) \text { were conducted by magnetic stirring at room temperature. } \\
\text { b Yields were calculated based on GC-FID analyses. } \\
\text { c } \text { The reactions with a fixed amount of formaldehyde }(2.0 \mathrm{mmol}) \text { and } p \text {-thiocresol } \\
\text { (2.0 mmol) were assisted by probe sonicator with amplitude at } 64 \text { micrometer. }\end{array}$} \\
\hline
\end{tabular}

In the next step, the reaction time was investigated under two activation methods. In the first series of arylthiomethylation of indole, the mixture of reactants were allowed to react under magnetic stirring for $1.5 \mathrm{~h}, 2.5 \mathrm{~h}, 3.5 \mathrm{~h}$ and $24 \mathrm{~h}$ at room temperature (Entries 4, 6-8, Table 2). In the second series, some reactions performed under the ultrasound irradiation were compared with those above (Entries 9-12, Table 2). We first investigated the effect of ultrasonic amplitudes at $48 \mu \mathrm{m}, 64 \mu \mathrm{m}, 80 \mu \mathrm{m}, 96$ $\mu \mathrm{m}$, and $128 \mu \mathrm{m}$ on the yield of desired indole. The results demonstrated that the most efficient amplitude to accelerate this reaction was at $64 \mu \mathrm{m}$ (Fig. 2). 


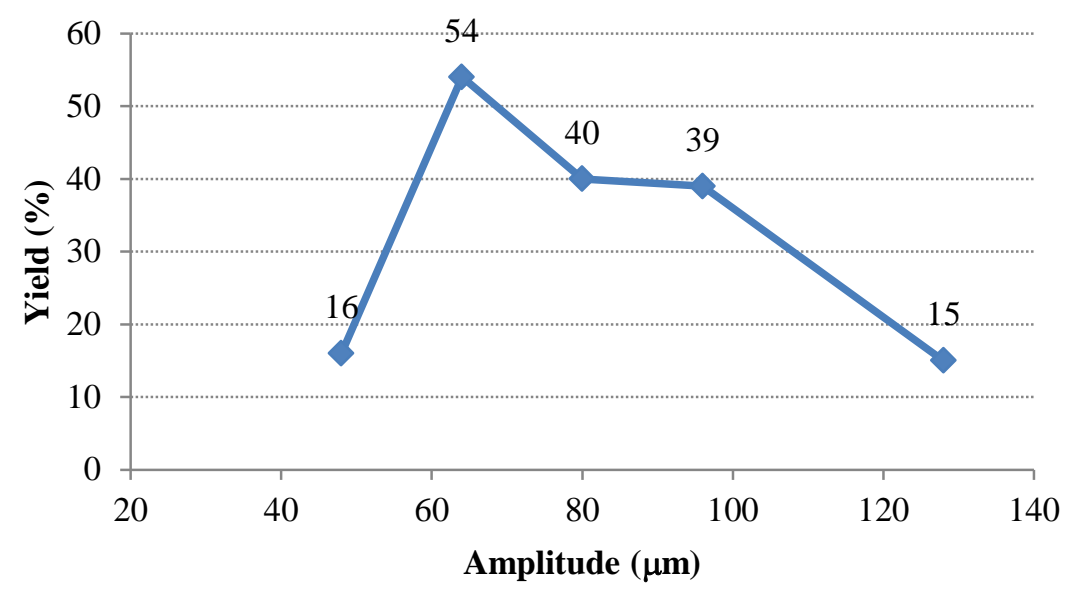

Fig. 2. Influence of amplitude on the efficiency of arylthiomethylation of indole to generate the 3-( $p$-tolylthiomethyl)-1Hindole under ultrasonic irradiation for $40 \mathrm{~min}$ (indole: $3.0 \mathrm{mmol}$, $p$-thiocresol: $2.0 \mathrm{mmol}$ and formaldehyde: 2.0 mmol)

The comparison of the experiments activated by two methods showed that a maximum yield of 4 obtained by the three-component reaction with acetic acid as catalyst reached $54 \%$ after forty-minute ultrasound irradiation, while it was $53 \%$ after three and half hour magnetic stirring. It could be explained that the disruption of the phase boundary, owing to a formation of extremely fine emulsions from the mixture of immiscible liquids under ultrasonic irradiation, increased the interfacial contact area between the reactant layers [10].

\section{CONCLUSION}

In summary, we have successfully developed an efficient and mild synthetic protocol of 3-(ptolylthiomethyl)- $1 H$-indole via three-component reaction of indole, $p$-thiocresol and the solution of formaldehyde (36\%) in the presence of acetic acid as catalyst. Ultrasound irradiation has influenced significantly on the reduction of the reaction time without any loss of product yield in comparison with magnetic stirring.

\section{Bức xạ siêu âm xúc tiến sự arylthiometyl hóa indol qua phản ứng đa thành phần trong môi trường nước dưới sự xúc tác của acetic acid}

- Lưu Thi Xuân Thi

Trường Đại học Khoa học Tự nhiên, ĐHQG-HCM

- Phạm Quang Vinh

Trường THCS Lê Hồng Phong- Đồng Nai

\section{TÓM TẮT}

Phản ứng đa thành phần (MCRs) đóng vai trò quan trong để tạo ra các phân tư phíc tạp theo quy

trình phản ưng một bước. Dựa trên cơ chế và quy trình phản ưng Mannich trong sụ điều chế Grammin,

\section{Trang 84}


sụ arylthiometyl hóa của indol được thục hiện vói ba chất phản ứng: indol, p-thiocresol và dung dịch formaldehyd (36\%) duoói hai phuong pháp kich hoạt nhu khuấy tù và siêu âm. Sản phẩm chính 3-(p-

Tù khóa: arylthiometyl hóa, búc xa siêu âm, acetic acid và indol

\section{REFERENCES}

[1]. A.B. Smith, Y.S. Cho, H. Ishiyama, Nodulisporic acid a synthetic studies. 2. Construction of an Eastern hemisphere subtarget, Organic Letters, 3 , 3971- 3974 (2001).

[30]. H. Hagiwara, K. Kobayashi, S. Miya, T. Hoshi, T. Suzuki, M. Ando, T. Okamoto, M. Kobayashi, I. Yamomoto, S. Ohtsubo, M. Kato, H. Uda, First total syntheses of the phytotoxins solanapyrones D and E via the Domino Michael protocol, Journal of Organic Chemistry, 67, 5969-5976 (2002).

[31]. H. Abdel-Ghany, A.M. El-Sayed, A. Khodairy, H. Salah, Synthesis of new 3-substituted and spiro 1,5-benzodiazepin-2-ones under phase-transfer catalysis conditions, Synthetic Communications, 31, 2523-2535 (2001).

[32]. G. Ramachandran, N.S. Karthikeyan, P. Giridharan, K.I. Sathiyanarayanan, Efficient iodine catalyzed three components domino reaction for the synthesis of 1-(phenylthio) (phenyl)methyl) pyrrolidin-2-one derivatives possessing anticancer activities, Organic and Biomolecular Chemistry, 10, 5343-5346 (2012).

[33]. M. Yamauchi, S. Katayama, T. Watanabe, 2Methylthiomethylation of 1,3-dicarbonyl compounds and synthesis of 2-methylene-1,3dicarbonyl compounds, Synthesis, 11, 935-936 (1982).
tolylthiometyl)-1H-indol thu được với hiệu suất khá cao $(54 \%)$ trong thời gian ngắn (40 phút) duói sư kich hoạt của thanh siêu âm.
[34]. R. Mudududdla, R. Sharma, S.K. Guru, M. Kushwaha, A.P. Gupta, S.S. Bharate, S. Aravinda, R. Kant, S. Bhushan, R.A. Vishwakarma, S.B. Bharate, Trifluoroacetic acid catalyzed thiophenylmethylation and thioalkylmethylation of lactams and phenols via domino threecomponent reaction in water, RSC Advances, 4, 14081-14088 (2014).

[35]. Y. Gu, J. Barrault, F. Jérôme, Trapping of active methylene intermediates with alkenes, indoles or thiols: towards highly selective multicomponent reactions, Advanced Synthesis and Catalysis, 351, 3269-3278 (2009).

[36]. F. Poppelsdorf, S.J. Holt, Reactions of thiols and thioethers. Part I. An analogue of the Mannich reaction involving thiols, formaldehyde, and active methylene or methylidyne compounds, Journal of the Chemical Society (resumed), 11241130 (1954).

[37]. V.G. Nenajdenko, A.V. Statsuk, E.S. Balenkova, Reaction of 2-methylene-1,3-dicarbonyl compounds containing a $\mathrm{CF}_{3}$-Group with 1,3 dienes, Tetrahedron, 56, 6549-6556 (2000).

[38]. T.J Mason, J.P. Lorimer, Sonochemistry: Theory, applications and uses of ultrasound in chemistry, West Sussex, Ellis Horwood (1988). 